\section{Assessing the role of appropriate primary health care on the use of dental services by Brazilian low-income preschool children}

\author{
Avaliação do papel da atenção primária adequada \\ no uso de serviços de saúde bucal por \\ pré-escolares brasileiros de baixa renda
}

\author{
Evaluación del papel de la atención primaria \\ apropiada en el uso de los servicios de salud \\ bucal por parte de preescolares brasileños \\ de baja renta
}

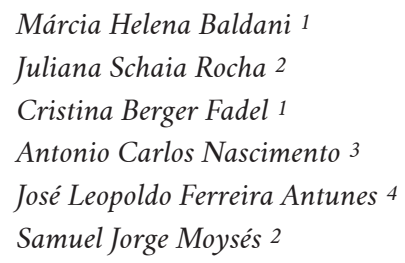

doi: 10.1590/0102-311X00158116

\begin{abstract}
This cross-sectional study aimed to assess the association between the quality of primary health care (PHC) and the use of dental services by preschoolers served by the Family Health Strategy (FHS), controlling for socio-demograph$i c$ determinants and perceived need. The sample encompassed 438 children aged 3-5 years, enrolled in 19 FHS facilities in Ponta Grossa, Paraná State, Brazil. Individual level variables were collected by interviewing parents or caregivers at home. They answered a questionnaire on socioeconomic conditions, oral hygiene habits and use of dental services. Parental perception of child's oral health related quality of life, as perceived need, was assessed by the Brazilian version of Early Childhood Oral Health Impact Scale

Correspondence

M. H. Baldani

Faculdade de Odontologia, Universidade Estadual de Ponta Grossa.

Av. Carlos Cavalcante 4748, Bloco M, Ponta Grossa, PR 84030-900, Brasil.

mbaldani@uepg.br

1 Faculdade de Odontologia, Universidade Estadual de Ponta Grossa, Ponta Grossa, Brasil.

2 Pontifícia Universidade Católica do Paraná, Curitiba, Brasil. 3 Universidade Positivo, Curitiba, Brasil.

4 Faculdade de Saúde Pública, Universidade de São Paulo, São Paulo, Brasil.
\end{abstract} (ECOHIS). Normative need was assessed by oral examinations, according to guidelines standardized by the World Health Organization. The contextual level factor was defined as the extent of implementation of PHC in the facilities. Managers responded to PCATool-Brazil, a validated questionnaire which measures the extent of PHC. Dentists answered to a version of PCATool, which was adapted and pretested for dental services. Multilevel analysis, based on Andersen's behavioral model, fitted the adjustment of "having ever consulted a dentist" to contextual and individual covariates. We observed high prevalence of dental caries. Almost half of the sample had had dental appointments in life. Social gradients were observed for the use of dental services. Although it was not able to eliminate the impact of adverse social conditions, higher levels of PHC attributes in dental services favored the effective use of such services by low-income children.

Dental Health Services; Primary Health Care; Health Care Quality, Access, and Evaluation; Preschool Child 


\section{Introduction}

Despite the widespread decline in prevalence, dental caries remain the most frequent oral disease affecting children, and it occurs with higher frequency and severity in disadvantaged populations 1 . Deprived children are less likely to receive dental care and more likely to have unmet needs 2,3 . Furthermore, the so-called social gradient of caries is enlarged when children are subject to health services that are not specifically prepared to deal with the individuals' actual needs 4 .

In Brazil, the oral health conditions of the population have been monitored by the Ministry of Health and are well documented in nationwide surveys reports 5 . They show a significant decline in caries prevalence in permanent teeth of 12-year-old children over the years, which is higher in areas with fluoridated water supply 6 . The most recent surveys - SBBrasil 20037 and 20108 - showed that, although to a lesser extent, the caries prevalence for primary teeth of preschool children has also declined. In regards to treatment need, these surveys showed a reduction in the proportion of untreated cavitated lesions for 12-year-old children. However, for preschoolers, the pattern of lack of access to dental care has remained unchanged over the years. SBBrasil 2010 showed that, similarly to $2003,80 \%$ of deciduous teeth affected by caries at the age of five remained untreated 7,8 .

To reduce oral health inequalities and inequities in access to dental services, interventions need to target distinct determinants, especially those that may lead to unfair, unnecessary and avoidable differences 9. A wide range of factors contributes to facilitating or restricting access to and use of health services; these factors have been integrated into an explanatory model proposed by Andersen 10 . According to Andersen's behavioral model, the use of health services results from the interaction of some individual factors, health system characteristics, the social context, and the individuals' past experiences in accessing services. Therefore, the use of health services is supposed to be a function of the individual predisposition (influenced by socio-demographic characteristics, preferences and expectations in relation to health and knowledge about the services), the level of need (self-perception, disease severity, activity limitations), and the presence of factors that enable the use of health services (income, social support, regular source of care) 10.

Starfield 9 stated that every health system has two main goals: (1) To optimize health levels by using the most advanced knowledge regarding the causes and the management of diseases; and (2) To minimize disparities among population subgroups so certain individuals are not disadvantaged in accessing health services or reaching the best levels of health. A primary health care (PHC)-oriented system is supposed to allow the achievement of these goals. Studies have reported that high levels of PHC attributes relate to greater effectiveness and equity in health care 11.

The Brazilian Unified National Health System (SUS) has been one of Brazilian society's main achievements toward the consolidation of social rights, specifically since it guarantees universal and comprehensive access to health services. In this context, the Family Health Strategy (FHS) is a community-based approach developed to provide regular PHC, including dental care. This program has become the main strategy for the reorganization of Brazilian health services at the PHC level 12 .

During the second half of the twentieth century, Brazilian oral health policies have mainly targeted schoolchildren aged 6-12 years. The other segments of the population have received only a few procedures focused on emergency services, restorative care and tooth extractions ${ }^{5}$. The FHS, added to the programmatic guidelines of the National Oral Health Policy (called Smiling Brazil), aims to break away from the traditional, old curative model of public dental services provision and to increase equity in access to care, including all ages groups 5 .

The official document of the Brazilian PHC policy stipulates that evaluating is necessary to advance the improvement of the quality and access to care 13 . A previous study on access to dental care for children living in FHS catchment areas with PHC-oriented dental services was performed in Ponta Grossa, a city in Southern Brazil, in 2007-2008 4. Results showed that those regularly monitored by PHC multi-professional teams had higher odds of having ever consulted a dentist 4 . Considering the above, the objective of this study was to assess the association between PHC quality delivered at Ponta Grossa's FHS facilities and the use of dental services by preschoolers, controlling for demographic, socioeconomic and need determinants. 


\section{Methods}

\section{Study design and population}

This cross-sectional study was approved by the Ethics Research Committee of Ponta Grossa State University and was supported by the Municipal Health Department. The target population was preschool children enrolled in the FHS facilities in the urban area of Ponta Grossa, a city with nearly 340,000 inhabitants, located in Paraná State, Brazil.

The city hosts a Regional Health Department, which is a reference in high technology services for 12 smaller municipalities in surrounding areas. In 2010, when this research was planned, there were 21 FHS facilities in urban areas, 14 of which had dental health teams working under PHC-oriented practices. All of the other facilities offered dental services under the traditional curative model. Two of the 21 FHS facilities were excluded from the research design because they were closed for renovation during the period of data collection. The characteristics of the workforce and services delivered in the FHS facilities are summarized in Table 1.

To assess the proposed objective, we designed a multilevel study encompassing Andersen's behavioral model for use of health services as a theoretical framework 10. The quality of PHC provided at the FHS facilities entered the model at the contextual level, while the predisposing, enabling and need factors were allocated as individual factors. The chosen dependent variable was whether the child had ever consulted a dentist.

\section{Data collection}

\section{- Contextual level}

The quality of health services was assessed by the provider version of the Primary Care Assessment Tool (PCATool), which should be answered by the facility's manager, who is usually a nurse in the FHS. The PCATool measures the presence of four essential attributes (or domains), which are recognized as the structural bases of PHC well-oriented services: (a) access to first contact, (b) longitudinality (relational continuity of care), (c) integrality (comprehensiveness of available and provided services), and

Table 1

Characteristics of the Family Health Strategy (FHS) facilities, according to dental service provision model. Ponta Grossa, Paraná State, Brazil, $2011-2012$.

\begin{tabular}{|c|c|c|}
\hline Characteristics & FHS/TD & FHS/DHT \\
\hline Organization & FHS facilities with traditional curative dental services & $\begin{array}{c}\text { FHS facilities with PHC-oriented dental care provided } \\
\text { by dental health teams }\end{array}$ \\
\hline $\begin{array}{l}\text { Total number in the } \\
\text { municipality }\end{array}$ & 7 in urban areas; 2 in rural areas & 14 in urban areas \\
\hline $\begin{array}{l}\text { Total number enrolled in the } \\
\text { research }\end{array}$ & 6 in urban areas & 13 in urban areas \\
\hline $\begin{array}{l}\text { Model of overall health and } \\
\text { dental care provision }\end{array}$ & $\begin{array}{l}\text { Multi-professional groups; FHT work under the } \\
\text { FHS guidelines, which are PHC-oriented; Dental } \\
\text { professionals act apart from the FHS, under } \\
\text { traditional curative dentistry practices }\end{array}$ & $\begin{array}{l}\text { Multi-professional groups; Both overall health teams } \\
\text { and DHT are supposed to work together, under the } \\
\text { FHS guidelines, which are PHC-oriented }\end{array}$ \\
\hline Human resources & $\begin{array}{l}\text { FHT - doctors, nurses, nursing assistants and } \mathrm{CHW} \text {; } \\
\text { Dental services are provided by dentists and dental } \\
\text { assistants }\end{array}$ & $\begin{array}{l}\text { FHT (with DHT) - doctors, dentists, nurses, nursing } \\
\text { and dental assistants, dental hygienists and } \mathrm{CHW}\end{array}$ \\
\hline $\begin{array}{l}\text { Management of population } \\
\text { demand for dental health } \\
\text { services }\end{array}$ & $\begin{array}{l}\text { Urgencies; Spontaneous/unscheduled demand; } \\
\text { Scheduled appointments }\end{array}$ & $\begin{array}{l}\text { Urgencies; Spontaneous/unscheduled demand; } \\
\text { Scheduled appointments; Health promotion, educative } \\
\text { and preventive actions targeted to all ages and groups }\end{array}$ \\
\hline
\end{tabular}

CHW: community health workers; DHT: dental health teams; FHT: family health teams; PHC: primary health care; TD: traditional dentistry. 
(d) coordination of health care within the health system. It also encompasses three derived attributes that qualify the actions in primary care: (a) family-centered care, (b) community-oriented care, and (c) cultural sensitivity 9 .

The self-applicable PCATool consists of Likert-type response questions, providing scores for each of the attributes, as well as a general score for the quality of the PHC process in the service, which ranges from 0-10. Services scoring 6.6 or more are considered to have high levels of PHC attributes or an appropriate primary care process 9 . We used the self-applicable validated Brazilian form (PCATool-Brazil), which has been recommended by the Ministry of Health for services evaluation 14.

A proxy for the quality of dental care at the PHC facilities was obtained with two variables: (a) the characteristics of dental care organization, considered as dental health teams working under PHC-oriented practices (DHT), or dental professionals providing traditional curative dentistry (TD) (Table 1); and (b) a version of PCATool-Brazil remodeled for oral health services and pre-tested in a cross-sectional study in Curitiba, Paraná State 15. This tool encompassed the same domains of the original version, both for essential and derived attributes, with the only difference being related to the measurement of integrality since the adapted version considered two dimensions: comprehensive clinical dental care and comprehensive oral health care (including health promotion, prevention and curative care) 15 . The PCATool-Brazil remodeled for oral health services was answered by the dentists at the facilities.

The health professionals were informed about the research objectives and had full autonomy in deciding on their participation. All managers and dentists agreed to participate and answer the specific PCATool questionnaires.

\section{- Individual level}

The study focused on 3-5-year-old children enrolled in the FHS facilities and who had actually been using their services. Three specific questions were applied at the beginning of the interview to identify whether a child was under the inclusion criteria: (a) Is there a health care service to where you usually take your child when he/she is sick or when you need some advice about his/her health condition? Which one?; (b) Is there a health care service where the professionals know your child quite well? Which one?; (c) Is there a doctor you consider the most responsible for providing health care to your child? Where does he/she work?

The study included all children whose caregivers indicated the FHS as the reference service for their health needs in at least one of these questions. Three answers indicating the FHS facility or one of its health professionals as the reference characterized interpersonal continuity to the service. Parents who agreed to participate signed a free and informed consent.

The sample size was calculated considering the city's estimated population of 4-5-year-old children in $2009(15,321)$ with a 5\% degree of accuracy, a 95\% confidence interval (95\%CI) and a 1.2 clustering design effect 16 for a $50 \%$ caries prevalence, which resulted in 450 children. The final sample size was increased by about $10 \%$ to compensate for possible losses, totaling 500 individuals. The FHS facilities included in the study were assumed to be "conglomerates". For each one, the random selection of participants observed a simple sampling design, maintaining the proportional relation between the calculated number of children and the total number of population enrolled in the service.

Ten trained dental students performed data collection in households from March 2011 to May 2012. The data collection encompassed interviews with mothers or the closest caregivers and children's dental examination. If the selected mother, guardian or child was not located at home during the visit, one additional attempt was made on a subsequent day and at a different time.

The questionnaire related to socioeconomic and behavioral characteristics, perceived need and use of dental services fitted the individual determinants of Andersen's behavioral model 10 and was pre-tested in a pilot study. Perceived need was assessed using the validated Brazilian version of the Early Childhood Oral Health Impact Scale (ECOHIS) 17,18,19, which consists of 13 questions that assess the impact of oral conditions on children's and families' quality of life. The answer options are arranged in a five-point Likert scale ranging from 0-4 (never to very often). The final index ranges from 0-52 (no impact to maximum impact) 17. 
Clinically evaluated need was defined as dental caries experience, assessed in terms of the number of decayed, missing due to caries and filled primary teeth (dmft), which were obtained according to World Health Organization (WHO) criteria, as applied in SBBrasil 2010 20. The researchers were calibrated during the examination of a group of twenty 3-5-year-old children, who were excluded from the final sample. The exams occurred in duplicate within a two-day interval. The lowest acceptable inter- and intra-examiner agreement values were kappa $=0.7$.

The use of dental services was assessed by two questions: (a) if the child had consulted a dentist at some point in life; and (b) the time and reasons for the last dental appointment.

\section{Data analysis}

We entered the data on Excel spreadsheets (Microsoft Corp., USA) and double-checked them. The statistical analyses were carried out using the software Stata 11.1 (StataCorp LP, College Station, USA). Descriptive statistics were performed to characterize the extent of the PHC attributes of the facilities and the individual characteristics of the sample. After a Kolmogorov-Smirnov test for normality, differences between the attribute scores were assessed by Student t-test. The significance level was set at $5 \%$.

The independent associations between the outcome - having ever been to a dentist - and the explanatory variables in contextual and individual levels were assessed by bivariate analysis. All covariates independently associated with the outcome at the level of $20 \%$ or less $(p \leq 0.20)$ were selected to fit the multivariate analysis. For the individual level, predisposing factors were grouped into two domains: (a) socio-demographic - age, education level of the mother or main caregiver and household overcrowding; and (b) health beliefs and attitudes - if the child had the teeth brushed daily and if the mother would take her child to the dentist if necessary. As enabling factors, the chosen variables were: (a) socioeconomic status (according to Brazilian Economic Classification, ranked in high, mid-high, mid-low and low) 21; (b) if the child lived in nuclear families; and (c) the child's school attendance. Need of dental care was identified both by perceived and clinically evaluated need.

A multilevel regression analysis with fixed effects 22 was performed to assess the explanatory model for the use of dental care. At the first level of the analysis, we obtained an adjusted model for dental care use including only the contextual variables. At the second level, three blocks of variables (referring to the dimensions of the individual determinants of Andersen's model: block $1=$ predisposing factors; block 2 = enabling factors; block 3 = need factors) were sequentially included and adjusted the association between the outcome and contextual covariates. As the use of dental services was relatively common, statistical analyses used Poisson regression 23 . Results were reported as non-adjusted and adjusted prevalence ratios with $95 \%$ CI.

\section{Results}

The final sample encompassed 456 children enrolled in the services of 19 urban FHS facilities of Ponta Grossa, 13 of the facilities with PHC-oriented dental health teams and six with traditional curative dentistry (Table 1). Of the 500 children previously sampled, 44 were not assessed because their mothers/guardians were absent from the households or due to areas with limited access $(8.8 \%$ non-response rate). During the tabulation, 18 questionnaires with much missing information were excluded (3.9\%), resulting in the remaining 438 valid individuals' data.

At the contextual level, the scores of PHC attributes in the FHS ranged from 4.97-7.89 with an average of $6.65( \pm 0.92)$. Twelve facilities scored 6.6 points or more and were considered to provide good quality PHC. There were no differences between the mean scores of the attributes (essential or derived) for overall health services when comparing the groups of facilities with both models of dental services provision (Table 2). However, there were significant differences when comparing the scores of the specific oral health care attributes, which were higher for the PHC-oriented dental services, except for the essential attributes access to the first contact and curative clinical integrality (Table 2). In addition, greater proportions of high-level PHC attributes were identified among the FHS facilities with dental health teams ( 8 of $13,61 \%$ ), opposed to those with traditional curative dentistry (1 of $6,17 \%)$. 
Table 2

Quality of primary health care (PHC) in Family Health Strategy (FHS). Comparison of the extent of PHC attributes in overall health care and dental health care between two models of dental care provision. Ponta Grossa, Paraná State, Brazil, 2011-2012.

\begin{tabular}{|c|c|c|c|c|c|}
\hline \multirow[t]{2}{*}{ PHC quality assessment * } & \multicolumn{2}{|c|}{ FHS/DHT ** } & \multicolumn{2}{|c|}{ FHS/TD *** } & \multirow[t]{2}{*}{ p-value \# } \\
\hline & Mean & SD & Mean & SD & \\
\hline \multicolumn{6}{|l|}{$\mathrm{PHC}$ - overall health } \\
\hline \multicolumn{6}{|l|}{ Essential attributes } \\
\hline Access to first contact & 4.56 & 0.90 & 3.95 & 1.09 & 0.267 \\
\hline Longitudinality & 6.24 & 1.21 & 6.32 & 1.24 & 0.883 \\
\hline Integrality - available services & 6.73 & 1.36 & 6.87 & 0.81 & 0.778 \\
\hline Integrality - provided services & 7.55 & 1.63 & 7.41 & 1.42 & 0.850 \\
\hline Coordination of healthcare within the health system & 6.95 & 1.60 & 7.14 & 1.62 & 0.823 \\
\hline \multicolumn{6}{|l|}{ Derived attributes } \\
\hline Family orientation & 7.14 & 1.84 & 6.71 & 1.20 & 0.547 \\
\hline Community orientation & 7.77 & 1.18 & 7.82 & 1.19 & 0.932 \\
\hline Cultural competence & 7.36 & 1.59 & 7.22 & 0.92 & 0.812 \\
\hline PHC essential attributes in overall health care & 6.20 & 0.90 & 6.32 & 0.87 & 0.784 \\
\hline PHC derived attributes in overall health care & 7.42 & 1.29 & 7.25 & 1.00 & 0.753 \\
\hline PHC total attributes in overall health care & 6.61 & 0.95 & 6.63 & 0.86 & 0.959 \\
\hline \multicolumn{6}{|l|}{ PHC - oral health } \\
\hline \multicolumn{6}{|l|}{ Essential attributes } \\
\hline Access to first contact & 6.61 & 0.94 & 5.80 & 0.69 & 0.055 \\
\hline Longitudinality & 8.08 & 1.22 & 6.94 & 0.93 & 0.045 \\
\hline Integrality - curative procedures & 6.32 & 1.08 & 5.83 & 0.85 & 0.309 \\
\hline Integrality - wide oral health care (promotion, prevention and treatment) & 7.04 & 2.12 & 5.12 & 1.98 & 0.089 \\
\hline Coordination of healthcare within the health system & 8.20 & 1.25 & 8.05 & 2.82 & 0.905 \\
\hline \multicolumn{6}{|l|}{ Derived attributes } \\
\hline Family-centered care & 7.29 & 1.51 & 4.51 & 1.43 & 0.003 \\
\hline Community-oriented care & 6.30 & 1.57 & 3.25 & 2.03 & 0.012 \\
\hline Cultural sensitivity & 8.31 & 0.97 & 8.22 & 0.91 & 0.856 \\
\hline PHC essential attributes in oral health care & 7.24 & 0.95 & 6.35 & 0.99 & 0.097 \\
\hline PHC derived attributes in oral health care & 7.30 & 1.20 & 5.33 & 1.09 & 0.005 \\
\hline PHC total attributes in oral health care & 6.17 & 0.89 & 5.25 & 0.74 & 0.036 \\
\hline
\end{tabular}

SD: standard deviation.

* Research data - PCATool questionnaire, overall health services and dental health services, as answered by health professionals at the FHS facilities (scores range from 0 to 10, high levels are supposed to score 6.6 or more);

** FHS facilities with PHC-oriented dental care provided by dental health team;

*** FHS facilities with traditional curative dental services;

\# Student's t-test for unpaired samples.

As for the individual level, 51\% of the surveyed children were girls and 49\% were boys, with a mean age of 3.9 years $( \pm 0.8)$. Most of them belonged to mid-low income levels, lived in two-parent nuclear families with no household overcrowding and attended public preschools (Table 3). However, a polarization socially deprived group was identified, as $16 \%$ of the children belonged to low-income families, $9.6 \%$ of them lived in assigned houses or in irregular segregated areas and $10.7 \%$ of the households had domestic sewage that leaked into open air. The average age of the mothers - 29.4 years $( \pm 6.8)$ - showed a group of predominantly young women. Most of them had low schooling levels (Table 3).

With regard to oral hygiene habits, most of the mothers reported their children had their teeth brushed daily (Table 3). In addition, almost 60\% of them stated their children needed dental care, and $11.3 \%$ said they would take the child to consult the dentist only in case of pain. Table 3 also shows that $26.3 \%$ of the children had poorer quality of life due to oral conditions; $22 \%$ reported occasional dental pain and $4.3 \%$ frequent pain. 


\section{Table 3}

Descriptive characteristics of the sample according to socio-demographic and psychosocial characteristics. Children aged 3-5 years enrolled to the Family Health Strategy. Ponta Grossa, Paraná State, Brazil, 2011-2012.

\begin{tabular}{|c|c|c|c|}
\hline Characteristics & $\mathbf{n}$ & $\%$ & $95 \% \mathrm{Cl}$ \\
\hline \multicolumn{4}{|l|}{ Age group (years) } \\
\hline 3 & 165 & 37.7 & $33.3-41.8$ \\
\hline 4 & 153 & 34.9 & 30.4-39.3 \\
\hline 5 & 120 & 27.4 & 23.3-31.5 \\
\hline \multicolumn{4}{|l|}{ Sex } \\
\hline Girls & 222 & 50.7 & 46.1-55.5 \\
\hline Boys & 216 & 49.3 & 44.5-53.9 \\
\hline \multicolumn{4}{|c|}{ Educational level of the mother or main caregiver } \\
\hline Elementary school completed or less & 264 & 61.3 & $56.4-65.9$ \\
\hline High school completed or more & 167 & 38.7 & $34.1-43.6$ \\
\hline \multicolumn{4}{|l|}{ Parent(s) with whom child lives } \\
\hline Both parents & 319 & 73.3 & $68.7-77.2$ \\
\hline Only one parent or other caregiver(s) & 116 & 26.7 & $22.8-30.6$ \\
\hline \multicolumn{4}{|l|}{ Socioeconomic status * } \\
\hline High & 41 & 10.0 & 7.3-13.1 \\
\hline Mid-high & 141 & 34.2 & 29.6-38.8 \\
\hline Mid-low & 164 & 39.8 & $35.0-45.1$ \\
\hline Low & 66 & 16.0 & 12.6-19.7 \\
\hline \multicolumn{4}{|c|}{ Household overcrowding ( $\geq 3$ residents per room) } \\
\hline Yes & 146 & 34.8 & 30.3-39.4 \\
\hline No & 273 & 65.2 & $60.6-69.7$ \\
\hline \multicolumn{4}{|l|}{ Attends school/kindergarten } \\
\hline Yes & 261 & 60.6 & $56.1-64.5$ \\
\hline No & 170 & 39.4 & $35.5-43.9$ \\
\hline \multicolumn{4}{|l|}{ Child has the teeth brushed daily } \\
\hline Yes & 350 & 81.0 & 77.1-84.7 \\
\hline No & 82 & 19.0 & $15.3-22.9$ \\
\hline \multicolumn{4}{|l|}{ Frequency of daily toothbrushing } \\
\hline Once or less & 158 & 36.8 & $32.4-41.3$ \\
\hline Twice or more & 271 & 63.2 & $58.7-67.6$ \\
\hline \multicolumn{4}{|c|}{ Would take the child to the dentist if necessary } \\
\hline Yes & 361 & 88,7 & $85.5-91.9$ \\
\hline No/Only in case of pain & 46 & 11,3 & $8.1-14.5$ \\
\hline \multicolumn{4}{|l|}{ Child needs dental care } \\
\hline Yes & 243 & 57.9 & $52.9-62.6$ \\
\hline No & 177 & 42.1 & $37.4-47.1$ \\
\hline \multicolumn{4}{|l|}{ Oral health impact on quality of life } \\
\hline ECOHIS $\geq 1$ (some impact) & 115 & 26.3 & $22.4-30.4$ \\
\hline ECOHIS = 0 (no impact) & 332 & 73.7 & $69.6-77.6$ \\
\hline \multicolumn{4}{|l|}{ Dental caries experience $(\mathrm{dmft} \geq 1)$} \\
\hline Present & 225 & 51.4 & $47.0-56.2$ \\
\hline Absent & 213 & 48.6 & 43.8-53.0 \\
\hline
\end{tabular}

95\% Cl: 95\% confidence interval; dmft: decayed, missing due to caries and filled primary teeth; ECOHIS: Early Childhood Oral Health Impact Scale.

* According to Brazilian Economic Classification 21. 
The prevalence of dental caries was $51.4 \%$. The average $\mathrm{dmft}$ was $2.06( \pm 2.92)$. The decayed component comprised almost the total value of the index, with an average of $1.82( \pm 2.73)$, indicating that $88.4 \%$ of the affected teeth were untreated. The component missing represented $3.4 \%$ of the index, with an average value of $0.07( \pm 0.44)$. The average number of filled teeth was $0.17( \pm 0.74)$, indicating that only $8 \%$ of teeth affected by caries were treated.

Table 4 indicates that $42 \%$ of the sampled children had been to the dentist at least once in life. Only $19.8 \%$ of them sought the dentist at the FHS facility. Routine was the main reason for the last dental visit for $52.9 \%$ of the children who had visited the dentist. Dental pain or cavities were indicated as the reason for visiting a dentist for the mothers of 56 children, which corresponds to $40.6 \%$ of those who had ever used dental services. The results showed that only $25.1 \%$ of the sample referred to regular dental service for the child.

The multilevel analysis for unadjusted and adjusted associations between the outcome and the independent covariates is in Table 5. At the individual level, bivariate analysis identified that higher proportions of children who had never been to the dentist were found among the youngest, those with low socioeconomic status, those not enrolled in preschools, those living in household crowding conditions with only one parent and those whose parents/caregivers have low educational levels. Regarding oral health beliefs and attitudes, higher proportions of children who never had dental visits were found among those without daily tooth-brushing habits and those whose mothers reported they would take the child to the dentist only in case of pain. Opposite to this, a higher prevalence of children who have been to the dentist was found among those who had experienced dental caries and those who reported impact of oral health on quality of life.

At the contextual level, bivariate analysis identified that higher proportions of children who had consulted a dentist were found to be enrolled to FHS facilities with dental health teams and higher levels of PHC attributes in dental care (Table 5). Since we identified high association between the presence of dental health teams and the scores of attributes in dental care, only one contextual factor (high levels of PHC attributes) was selected for the adjusted analysis, to avoid multi-colinearity.

Table 4

Descriptive characteristics of the sample according to use of dental services. Children aged 3-5 years enrolled to the Family Health Strategy. Ponta Grossa, Paraná State, Brazil, 2011-2012.

\begin{tabular}{|c|c|c|c|}
\hline Characteristics & $\mathbf{n}$ & $\%$ & $95 \% \mathrm{Cl}$ \\
\hline \multicolumn{4}{|l|}{ Child's dental care attendance } \\
\hline Has ever been to a dentist & 184 & 42.0 & $37.2-46.6$ \\
\hline Has never had a dental visit & 254 & 58.0 & $53.7-62.8$ \\
\hline \multicolumn{4}{|c|}{ Has ever been informed about how to care for the child's teeth } \\
\hline Yes & 201 & 49.8 & $45.3-55.0$ \\
\hline No & 203 & 50.2 & $45.0-54.7$ \\
\hline \multicolumn{4}{|c|}{ Dental care visits in the previous year } \\
\hline Yes & 142 & 32.6 & $27.9-37.0$ \\
\hline No & 293 & 67.4 & $63.0-72.1$ \\
\hline \multicolumn{4}{|c|}{ Reason for the last dental care visit $(n=138)$} \\
\hline Routine visit, prevention & 73 & 52.9 & $44.2-61.6$ \\
\hline Dental pain & 31 & 22.5 & $15.9-29.0$ \\
\hline Caries, cavities & 25 & 18.1 & $12.3-24.6$ \\
\hline Other reasons & 9 & 6.5 & $2.9-10.9$ \\
\hline \multicolumn{4}{|c|}{ Referral to a regular dentist for the child } \\
\hline Yes & 109 & 25.1 & 20.9-29.1 \\
\hline No & 71 & 16.9 & $13.5-20.4$ \\
\hline Never had a dental visit & 254 & 58.0 & $53.7-62.8$ \\
\hline
\end{tabular}

95\% Cl: 95\% confidence interval. 


\section{Table 5}

Unadjusted and adjusted Poisson multilevel assessment for use of dental services at least once in life, according to Andersen's behavioral model 10. Children aged 3-5 years enrolled to the Family Health Strategy (FHS). Ponta Grossa, Paraná State, Brazil, 2011-2012.

\begin{tabular}{|c|c|c|c|c|c|c|}
\hline \multirow[t]{2}{*}{ Selected variables } & \multicolumn{6}{|c|}{ Has ever consulted a dentist } \\
\hline & $\mathbf{n}$ & $\%$ & $\mathrm{PR}_{\text {unadjusted }}(95 \% \mathrm{Cl})$ & p-value & $\mathrm{PR}_{\text {adjusted }}(95 \% \mathrm{Cl})$ & p-value \\
\hline \multicolumn{7}{|l|}{ Level 1 (contextual determinants) } \\
\hline \multicolumn{7}{|c|}{ Characteristics of health services provided at the FHS facilities } \\
\hline \multicolumn{7}{|l|}{ Model of dental care provision } \\
\hline DHT & 137 & 46.4 & 1.00 & & - & \\
\hline TD & 46 & 32.9 & $0.71(0.50-0.99)$ & 0.047 & & \\
\hline \multicolumn{7}{|l|}{ High levels of PHC attributes in overall health care * } \\
\hline No & 74 & 49.0 & 1.00 & & & \\
\hline Yes & 109 & 38.4 & $0.78(0.56-1,08)$ & 0.128 & - & \\
\hline \multicolumn{7}{|l|}{ High levels of PHC attributes in dental care * } \\
\hline No & 63 & 30.6 & 1.00 & & 1.00 & \\
\hline Yes & 120 & 52.4 & $1.71(1.26-2.32)$ & 0.001 & $1.71(1.26-2.32)$ & 0.001 \\
\hline Log likelihood (contextual level) ** & & & & & -335.186 & \\
\hline Wald chi-square & & & & & 11.98 & \\
\hline \multicolumn{7}{|l|}{ Level 2 (individual determinants) } \\
\hline \multicolumn{7}{|l|}{ Block 1 - predisposing factors } \\
\hline \multicolumn{7}{|l|}{ Socio-demographic } \\
\hline \multicolumn{7}{|l|}{ Age group (years) } \\
\hline 3 & 50 & 30.3 & 1.00 & & 1.00 & \\
\hline 4 & 75 & 49.0 & $1.64(1.14-2.35)$ & 0.007 & $1.49(1.03-2.15)$ & 0.033 \\
\hline 5 & 59 & 49.2 & $1.62(1.11-2.38)$ & 0.012 & $1.43(0.97-2.12)$ & 0.070 \\
\hline \multicolumn{7}{|l|}{ Educational level of the mother or main caregiver } \\
\hline High school completed or more & 85 & 50.9 & 1.00 & & & \\
\hline Elementary school completed or less & 97 & 36.7 & $0.73(0.54-0.99)$ & 0.035 & - & \\
\hline \multicolumn{7}{|l|}{ Household overcrowding } \\
\hline No & 133 & 48.7 & 1.00 & & 1.00 & \\
\hline Yes & 41 & 28.1 & $0.58(0.41-0.83)$ & 0.003 & $0.63(0.44-0.90)$ & 0.010 \\
\hline \multicolumn{7}{|l|}{ Health beliefs and attitudes } \\
\hline \multicolumn{7}{|l|}{ Child has the teeth brushed daily } \\
\hline No & 23 & 28.0 & 1.00 & & & \\
\hline Yes & 159 & 45.4 & $1.60(1.03-2.49)$ & 0.036 & - & \\
\hline \multicolumn{7}{|l|}{ Would take the child to the dentist if necessary } \\
\hline No/Only in case of pain & 12 & 26.1 & 1.00 & & & \\
\hline Yes & 164 & 45.4 & $1.74(0.96-3.13)$ & 0.067 & - & \\
\hline Log likelihood (contextual + predisposing factors) & & & & & -312.014 & \\
\hline Wald chi-square & & & & & 24.82 & \\
\hline
\end{tabular}

(continues)

The association between PHC quality and the use of dental services remained statistically significant in the adjusted final model. There were higher proportions of children who had ever consulted a dentist in areas with higher scores of PHC attributes in dental care, even controlling for predisposing, enabling and need factors. 
Table 5 (continued)

\begin{tabular}{|c|c|c|c|c|c|c|}
\hline \multirow[t]{2}{*}{ Selected variables } & \multicolumn{6}{|c|}{ Has ever consulted a dentist } \\
\hline & $\mathbf{n}$ & $\%$ & $\mathrm{PR}_{\text {unadjusted }}(95 \% \mathrm{Cl})$ & p-value & $\mathrm{PR}_{\text {adjusted }}(95 \% \mathrm{Cl})$ & p-value \\
\hline \multicolumn{7}{|l|}{ Level 2 (individual determinants) } \\
\hline \multicolumn{7}{|l|}{ Block 2 - enabling factors } \\
\hline \multicolumn{7}{|l|}{ Socioeconomic status $* * *$} \\
\hline High & 25 & 61.0 & 1.00 & & - & \\
\hline Mid-high & 66 & 46.8 & $0.77(0.48-1.22)$ & 0.260 & & \\
\hline Mid-low & 69 & 42.1 & $0.68(0.43-1.08)$ & 0.105 & & \\
\hline Low & 19 & 28.8 & $0.49(0.27-0.88)$ & 0.018 & & \\
\hline \multicolumn{7}{|l|}{ Parent(s) with whom child lives } \\
\hline Only one parent or caregiver & 35 & 30.2 & 1.00 & & 1.00 & \\
\hline Both parents (nuclear family) & 147 & 46.1 & $1.51(1.04-2.19)$ & 0.029 & $1.50(1.03-2.18)$ & 0.035 \\
\hline \multicolumn{7}{|l|}{ Attends school/kindergarten } \\
\hline No & 47 & 27.6 & 1.00 & & & \\
\hline Yes & 133 & 51.0 & $1.83(1.32-2.57)$ & $<0.001$ & - & \\
\hline Log likelihood (contextual + predisposing + enabling factors) & & & & & -306.574 & \\
\hline Wald chi-square & & & & & 29.20 & \\
\hline \multicolumn{7}{|l|}{ Block 3 - need factors } \\
\hline \multicolumn{7}{|l|}{ Oral health impact on quality of life } \\
\hline $\mathrm{ECOHIS}=0$ (no impact) & 110 & 34.1 & 1.00 & & 1.00 & \\
\hline ECOHIS $\geq 1$ (some impact) & 74 & 64.3 & $1.89(1.40-2.54)$ & $<0.001$ & $1.56(1.13-2.15)$ & 0.007 \\
\hline \multicolumn{7}{|l|}{ Dental caries experience $(\mathrm{dmft} \geq 1)$} \\
\hline Absent & 75 & 35.2 & 1.00 & & & \\
\hline Present & 109 & 48.4 & $1.36(1.01-1.84)$ & 0.040 & - & \\
\hline $\begin{array}{l}\text { Log likelihood (contextual + predisposing + enabling + need } \\
\text { factors) }\end{array}$ & & & & & -303.016 & \\
\hline Wald chi-square & & & & & 37.41 & \\
\hline
\end{tabular}

95\%Cl: 95\% confidence interval; DHT: dental health teams; dmft: decayed, missing due to caries and filled primary teeth; ECOHIS: Early Childhood Oral Health Impact Scale; PHC: primary health care; PR: prevalence ratio; TD: traditional dentistry.

* PCATool total scores of 6.6 or more;

** Log likelihood (empty model): -341.111;

*** According to Brazilian Economic Classification 21.

\section{Discussion}

Socioeconomic disparities in children's oral health is one of the most important public health issues, and they can be addressed through increasing access to dental care 2,24. Starfield 11 has demonstrated the positive impact of PHC on health conditions and equity in health care, including a review of the results of FHS in Brazil, and has stated that stronger primary care should produce better outcomes than weaker primary care. This study tested the hypothesis that, in addition to individual socioeconomic and psychosocial determinants, inequalities in the use of public dental services for Brazilian low-income preschool children are mediated by the quality of the primary care system. Thus, oral health services with high PHC attributes should favor dental visits for children and would have the potential to minimize the social gradient in access.

There are some aspects of a health system, as universal coverage, equitable distribution of resources according to need and comprehensiveness of services, which enable primary care attributes to thrive 11. The current Brazilian health system was established in 1988 according to three doctrinal principles: universal access to services, equity orientation, and comprehensive provision of all complexity levels of health care. PHC has been the guiding axis of the organization of SUS, and FHS has widely improved the quality of the system 11,12 . 
We observed that most of the FHS facilities scored high levels of PHC attributes for overall health care in Ponta Grossa, except for the access to first contact, which can be explained by the services' opening schedules defined by the Municipal Health Department. Nevertheless, in regards to dental services, FHS facilities with dental health teams reached higher scores of attributes than those with traditional curative dentistry, confirming the potential of this kind of arrangement to ensure PHCoriented dental services. Though our results reinforce the importance of FHS as a guiding model for primary dental care the variability in the scores of the attributes and the lack of differences for two important attributes (access to first contact and curative clinical integrality) indicates that the simple adoption of FHS as a care model is not enough; it is necessary to invest in skilled labor processes for managers and oral health teams.

One of the principles of the FHS, as defined by the Ministry of Health, is the prioritization of cities' underserved populations for the definition of the coverage areas of the facilities 13. Children participating in the present study were characterized as mid-low to low socioeconomic status, and they concur with the profile of the overall population covered by FHS in Ponta Grossa, as observed in the information assessed from the Primary Health Care Information System at the Health Department.

The distribution and polarization of the $\mathrm{dmft}$ index in this study's sample have been previously described 25. Our results revealed high prevalence of dental caries among children aged 3-5 years. Although almost half of them have been to a dentist at least once, we observed that access to restorative treatment is insufficient, so the majority of teeth affected by decay were not filled. Despite FHS facilities with dental health teams scoring higher in PCATool attributes than those with traditional curative dentistry, there were no statistical differences for caries prevalence, reported dental pain or prevalence of treated teeth (filled or extracted) 25 . This information agrees with the findings presented in Table 2; the mean scores of the essential attributes access to first contact and curative clinical integrality did not differ.

According to SBBrasil 2010, dental caries affected 53.4\% of Brazilian preschoolers aged five years 8. Among the children participating in the present study, the prevalence of caries was $51.4 \%$, which is high when compared with data from the Ministry of Health's survey even though this sample included a younger population. Other cross-sectional studies conducted in Brazilian cities also described lower prevalence of dental caries in preschool children than that observed in Ponta Grossa 26,27,28. However, a striking feature is that, as for Ponta Grossa, these studies also showed that the proportion of filled teeth was very low, even among children who have been to the dentist 26,27,28.

PHC strategies are intended to avoid or slow the development of diseases by eliminating or reducing factors related to them ${ }^{29}$. Although there is uncertain evidence in regards to the effectiveness of educative programs in avoiding caries development 30 , studies have shown that early preventive dental care is cost-effective and can reduce the need of further restorative treatment, mainly in highrisk populations $1,29,31,32$.

In Brazil, pregnant women and children aged 0-2 years have the higher priority within the public health services network, which includes dental care. However, early access to dental services is a challenge in most Brazilian municipalities, even after the adoption of the FHS. In Ponta Grossa, the proportion of children aged 3-5 years who have been to the dentist was $42 \%$. A previous study performed in the same city in 2007-2008 showed that $49.5 \%$ of the children aged up to six years living in the FHS areas had already received dental appointments 4 . These results are higher than those obtained in other Brazilian cities 26,28,33,34. Notwithstanding, none of these studies have restricted the sampling to children enrolled in the FHS coverage areas.

Health professionals have an important role in promoting children's use of dental care. Health care providers' recommendation that their patients visit the dentist in the first year of life was associated with an increase in dental visits among young U.S. children 35 . Interpersonal continuity with the FHS was shown to enable access to dental care for Brazilian children aged newborn to 14 years 4 . Though longitudinality is a main essential attribute of PHC, in the present study, only half of the mothers identified the FHS as a regular source of health care for their children. Regarding interpersonal continuity for dental care, the proportions were even lower. Among the children who had ever used dental services, $59 \%$ referred to a regular dentist, and only 68 mothers (38\%) indicated that it was the FHS oral health professional. 
In this study, higher proportions of children who had ever consulted a dentist were found among those living in FHS areas with dental health teams and with higher scores of PHC dental care attributes. A previous report of these data 25 showed that the FHS facilities with oriented dental services had greater proportions of children who had been to the dentist than those with traditional curative dentistry, both among those who had had toothache (71\% vs. 52\%, p = 0.09) and among those who had never had dental pain ( $38 \%$ vs. $26 \%$, p $=0.03$ ).

There is major evidence regarding the relation between children's use of dental services and socioeconomic 1,3,26,28,34,36 and psychosocial determinants 4,24,26,34. In accordance with that evidence, our study also identified lower rates of use of dental services among children with the worst social conditions or poorer oral hygiene habits, and higher rates of dental visits among those with related impact of oral health on quality of life.

Many authors have reviewed the evidence regarding the value of PHC and found strong PHC contributes to the performance of the health systems in terms of effectiveness, equity and improvement of population health 11. We observed that high levels of PHC attributes in oral health have favored the use of dental services for children. The quality of primary dental care, as measured by the adapted PCATool, was independently associated with the children's use of dental service, even after controlling for the individual determinants in terms of age, socioeconomic conditions, family structural constitution and the impact of oral health on quality of life.

Although the quality of primary dental care provided at the FHS facilities can increase young children's use of dental services, this study demonstrated it could not eliminate the effect of individual determinants. A time series longitudinal study performed in Spain - which also has a national health system characterized by universal coverage - observed that, regardless of the objective of achieving a wide coverage of dental care for children, and the increase in the proportion of children who have ever consulted a dentist, the health policies were not capable of eliminating socioeconomic inequalities when accessing dental services 3 .

This study has some limitations. The cross-sectional design does not allow the results to establish causal links. In addition, assessing PHC quality based on the perceptions of professionals may have led to a more favorable evaluation, overvaluing the attributes of services 37 . Concerning individual data, we cannot rule out the possibility of response bias, because the findings are based on perceptions and self-reports of the mothers/caregivers. However, some proceedings were taken to minimize response bias through the use of a validated questionnaire and the execution of a pilot study.

Although there were no refusals to participate, it was impossible to survey the mothers/guardians absent from the households or those living in areas with limited access. Their children could differ in dental care use and access patterns. In addition, two FHS facilities were unavailable during the data collection. The current sampling methods have limitations for certain populations living in locations of difficult access 16 . While most of the selected subjects were interviewed, and despite absent discrepancies of socio-demographic characteristics between excluded and selected areas, special care is required to allow inference of these results for the total FHS in the city.

Concerning the contextual information, we assessed the PHC attributes in dental services by using a questionnaire modified from the original version of PCATool. Despite both the professionals' and users' versions being tested in a wide cross-sectional study 15 , the versions have not been validated in terms of internal consistency, reliability or construct validity. As we compared two different types of dental services provided at the FHS facilities, and as we observed significantly higher levels of PHC attributes for the primary care-oriented one, it is possible to assume good convergent validity for the questionnaire. However, we cannot rule out the possibility of measurement bias.

The nature of research on social determinants and public policies often make sampling recommendations for multilevel analysis difficult to achieve 38, which occurred in this study. The main problem is related to the number of contextual units, since small samples should lead to some bias in the variance but would have little to no impact in the estimation of fixed effects 38 . This study's design and sampling method may have influenced the power of the multilevel analysis, given the small number of clusters (FHS facilities). The present results should be interpreted as a first exploratory insight for further research.

Despite the limitations, this study contributed with important information regarding the association between PHC quality and use of dental services by young children in underserved areas. 
Although incapable of eliminating the effect of unfavorable socioeconomic and psychosocial conditions, we showed that high levels of primary dental care attributes favored the use of services. The importance of this study lies in its results possibly fostering broader goals for public oral health policies, with focused approaches that promote the provision of and the resort to good quality primary dental care, even before the onset of diseases.

\section{Contributors}

M. H. Baldani, J. L. F. Antunes and S. J. Moysés participated in the study design, data analysis and data interpretation; writing and review of the article and; final approval of the version to be published. C. B. Fadel and J. S. Rocha contributed to the data analysis and data interpretation; critical review of content and; final approval of the version to be published. A. C. Nascimento collaborated in the study design; critical review of content and; final approval of the version to be published.

\section{Acknowledgments}

We acknowledge the local government of the municipality of Ponta Grossa, Paraná State, Brazil, and especially the community health workers of the FHS, for their assistance during the data collection. We also acknowledge the students of the Ponta Grossa State University for their valuable contribution to the data collection. Furthermore, we acknowledge Fundação Araucária (SESA-PR/MSDecit/CNPq,180/2010) for the financial support.

\section{References}

1. Darmawikarta D, Chen Y, Carsley S, Birken CS, Parkin PC, Schroth RJ, et al. Factors associated with dental care utilization in early childhood. Pediatrics 2014; 133:1594-600.

2. Allin S, Stabile M. Socioeconomic status and child health: what is the role of health care, health conditions, injuries and maternal health? Health Econ Policy Law 2012; 7:227.

3. Pinilla J, Negrín-Hernández MA, Abásolo I. Time trends in socio-economic inequalities in the lack of access to dental services among children in Spain 1987-2011. Int J Equity Health 2015; 14:9.

4. Baldani MH, Mendes YBE, de Campos Lawder JA, de Lara API, da Silva Rodrigues MMA, Antunes JLF. Inequalities in dental services utilization among Brazilian low-income children: the role of individual determinants. J Public Health Dent 2011; 71:46-53.

5. Pucca G, Gabriel M, de Araujo M, de Almeida F. Ten years of a National Oral Health Policy in Brazil: innovation, boldness, and numerous challenges. J Dent Res 2015; 94:1333-7.

6. Lauris JRP, da Silva Bastos R, de Magalhaes Bastos JR. Decline in dental caries among 12year-old children in Brazil, 1980-2005. Int Dent J 2012; 62:308-14.

7. Departamento de Atenção Básica, Secretaria de Atenção à Saúde, Ministério da Saúde. Projeto SB Brasil 2003: condições de saúde bucal da população brasileira no ano 2002-2003. Brasília: Ministério da Saúde; 2004.

8. Departamento de Atenção Básica, Secretaria de Atenção à Saúde, Ministério da Saúde. SB Brasil 2010. Pesquisa Nacional de Saúde Bucal. Resultados principais. Brasília: Ministério da Saúde; 2011.

9. Starfield B. Atenção primária: equilíbrio entre necessidades de saúde, serviços e tecnologia. Brasília: Organização das Nações Unidas para a Educação, a Ciência e a Cultura/Ministério da Saúde; 2002.

10. Andersen RM. Revisiting the behavioral model and access to medical care: does it matter? J Health Soc Behav 1995; 36:1-10.

11. Starfield B. Primary care: an increasingly important contributor to effectiveness, equity, and efficiency of health services. SESPAS report 2012. Gac Sanit 2012; 26:20-6.

12. Macinko J, Harris MJ. Brazil's Family Health Strategy: delivering community-based primary care in a universal health system. $\mathrm{N}$ Engl J Med 2015; 372:2177-81. 
13. Departamento de Atenção Básica, Secretaria de Atenção à Saúde, Ministério da Saúde. Política Nacional de Atenção Básica. Brasília: Ministério da Saúde; 2006.

14. Departamento de Atenção Básica, Secretaria de Atenção à Saúde, Ministério da Saúde. Manual do instrumento de avaliação da atenção primária à saúde: Primary Care Assessment Tool - PCATool. Brasília: Ministério da Saúde; 2010.

15. Nascimento A. Instrumentos de avaliação da atenção primária à saúde: revisão de literatura e metassíntese [Tese de Doutorado]. Curitiba: Pontifícia Universidade Católica do Paraná; 2011.

16. Bennett S, Woods T, Liyanage WM, Smith DL. A simplified general method for cluster-sample surveys of health in developing countries. World Health Stat Q 1991; 44:98-106.

17. Tesch FC, Oliveira BH, Leão A. Equivalência semântica da versão em português do instrumento Early Childhood Oral Health Impact Scale. Cad Saúde Pública 2008; 24:1897-909.

18. Scarpelli AC, Oliveria BH, Tesch FC, Leão AT, Pordeus IA, Paiva SM. Psychometric properties of the Brazilian version of the Early Childhood Oral Health Impact Scale (B-ECOHIS). BMC Oral Health 2011; 11:19.

19. Martins-Júnior PA, Ramos-Jorge J, Paiva SM, Marques LS, Ramos-Jorge ML. Validations of the Brazilian version of the Early Childhood Oral Health Impact Scale (ECOHIS). Cad Saúde Pública 2012; 28:367-74.

20. World Health Organization. Oral health surveys: basic methods. Geneva: World Health Organization; 2013.

21. Associação Brasileira de Empresas de Pesquisa. Critério de classificação econômica - Brasil. http://www.abep.org (acessado em 25/ Out/2010).

22. Snijders TAB, Bosker RJ. Multilevel analysis: an introduction to basic and advanced multilevel modelling. London: Sage Publications; 1999.

23. Barros AJD, Hirakata VN. Alternatives for logistic regression in cross-sectional studies: an empirical comparison of models that directly estimate the prevalence ratio. BMC Med Res Methodol 2003; 3:21.

24. Telleen S, Kim R, Young O, Chavez N, Barrett RE, Hall W, et al. Access to oral health services for urban low-income Latino children: social ecological influences. J Public Health Dent 2012; 72:8-18.

25. Hamati F, Rocha JS, Baldani MH. Prevalência de cárie, dor e uso de serviços odontológicos por crianças em áreas com e sem Equipes de Saúde Bucal na Estratégia Saúde da Família no município de Ponta Grossa, Paraná, Brasil. Rev Bras Pesqui Saúde 2014; 16:48-57.

26. Goettems ML, Ardenghi TM, Demarco FF, Romano AR, Torriani DD. Children's use of dental services: influence of maternal dental anxiety, attendance pattern, and perception of children's quality of life. Community Dent Oral Epidemiol 2012; 40:451-8.
27. Gomes MC, Pinto-Sarmento TC, Costa EM, Martins CC, Granville-Garcia AF, Paiva SM. Impact of oral health conditions on the quality of life of preschool children and their families: a cross-sectional study. Health Qual Life Outcomes 2014; 12:55.

28. Machry RV, Tuchtenhagen S, Agostini BA, da Silva Teixeira CR, Piovesan C, Mendes FM, et al. Socioeconomic and psychosocial predictors of dental healthcare use among Brazilian preschool children. BMC Oral Health 2013; 13:60.

29. Nowak AJ, Casamassimo PS, Scott J, Moulton $R$. Do early dental visits reduce treatment and treatment costs for children? Pediatr Dent 2014; 36:489-93.

30. Douglass JM, Clark MB. Integrating oral health into overall health care to prevent early childhood caries: need, evidence, and solutions. Pediatr Dent 2015; 37:266-74.

31. Sen B, Blackburn J, Morrisey MA, Kilgore ML, Becker DJ, Caldwell C, et al. Effectiveness of preventive dental visits in reducing nonpreventive dental visits and expenditures. Pediatrics 2013; 131:1107-13.

32. Fontana M. The clinical, environmental, and behavioral factors that foster early childhood caries: evidence for caries risk assessment. Pediatr Dent 2015; 37:217-25.

33. Camargo MBJ, Barros AJ, Frazão P, Matijasevich A, Santos IS, Peres MA, et al. Predictors of dental visits for routine check-ups and for the resolution of problems among preschool children. Rev Saúde Pública 2012; 46:87-97.

34. Granville-Garcia AF, Clementino MA, Gomes MC, Costa EM, Pinto-Sarmento TC, Paiva SM. Influence of oral problems and biopsychosocial factors on the utilization of dental services by preschool children. J Dent Child (Chic) 2015; 82:76-83.

35. Beil HA, Rozier RG. Primary health care providers' advice for a dental checkup and dental use in children. Pediatrics 2010; 126:435-41.

36. da Costa VPP, Goettems ML, de Oliveira LJC, Tarquinio SBC, Torriani DD, Correa MB, et al. Nonuse of dental service by schoolchildren in Southern Brazil: impact of socioeconomics, behavioral and clinical factors. Int J Public Health 2015; 60:411-6.

37. Reis RS, Coimbra LC, Silva AAM, Santos AM, Alves MTSS, Lamy ZC, et al. Access to and use of the services of the Family Health Strategy from the perspective of managers, professionals and users. Ciênc Saúde Coletiva 2013; 18:3321-31.

38. Bell BA, Morgan GB, Kromrey JD, Ferron JM. The impact of small cluster size on multilevel models: a Monte Carlo examination of twolevel models with binary and continuous predictors. In: JSM Proceedings - Section on Survey Research Methods. Alexandria: American Statistical Association; 2010. p. 4057-67. 


\section{Resumo}

Este estudo transversal procurou avaliar a associação entre a qualidade da atenção primária em saúde e o uso de serviços de saúde bucal por pré-escolares atendidos pela Estratégia Saúde da Família (ESF), ajustada por determinantes sóciodemográficos e necessidade percebida. A amostra compreendia 438 crianças entre 3 e 5 anos de idade, cadastradas em 19 serviços da ESF em Ponta Grossa, Paraná, Brasil. As variáveis de nível individual foram coletadas através de entrevistas domiciliares com os pais ou responsáveis, que responderam um questionário sobre condições socioeconômicas, hábitos de higiene bucal e uso de serviços odontológicos. A percepção dos pais sobre a qualidade de vida do filho relacionada à saúde bucal, ou necessidade percebida, foi avaliada com a versão brasileira da Early Childhood Oral Health Impact Scale (ECOHIS). A necessidade normativa foi avaliada pelo exame bucal, de acordo com as diretrizes padronizadas pela Organização Mundial da Saúde. O fator de nível contextual foi definido como o grau de implementação da atenção primária em saúde pelas unidades de saúde. Os coordenadores responderam o PCATool-Brasil, um questionário validado que mede o grau de atenção primária em saúde. Os cirurgiões-dentistas responderam uma versão do PCATool, adaptada e pré-testada em serviços odontológicos. A análise multinivel, baseada no modelo comportamental de Andersen, ajustou a variável de "ter consultado um dentista alguma vez na vida” às covariáveis contextuais e individuais. O estudo mostrou alta prevalência de cárie dentária. Quase a metade da amostra tinha história de consulta odontológica alguma vez na vida. Observamos gradientes sociais no uso de serviços de saúde bucal. Embora não tenha conseguido eliminar o impacto das condições sociais adversas, níveis maiores de atributos de atenção primária em saúde em serviços de saúde bucal favoreceram o uso efetivo desses serviços por crianças de famílias de baixa renda.

Serviços de Saúde Bucal; Atenção Primária à Saúde; Qualidade, Acesso e Avaliação da Assistência à Saúde; Pré-escolar

\section{Resumen}

Este estudio transversal tuvo como objetivo evaluar la asociación entre la calidad de la atención primaria en salud y el uso de servicios de salud bucal por parte de los preescolares, atendidos por el esquema Estrategia Salud de la Familia (ESF), ajustado por determinantes sociodemográficos $y$ necesidad percibida. La muestra comprendia a 438 niños entre 3 y 5 años de edad, registrados en 19 servicios de la ESF en Ponta Grossa, Paraná, Brasil. Las variables de nivel individual se recogieron a través de entrevistas domiciliarias con los padres o responsables, que respondieron un cuestionario sobre condiciones socioeconómicas, hábitos de higiene bucal y uso de servicios odontológicos. La percepción de los padres sobre la calidad de vida del hijo, relacionada con la salud bucal, o necesidad percibida, fue evaluada con la versión brasileña de la Early Childhood Oral Health Impact Scale (ECOHIS). La necesidad normativa se evaluó mediante el examen bucal, de acuerdo con las directrices estandarizadas por la Organización Mundial de la Salud. El factor de nivel contextual se definió como el grado de implementación de la atención primaria en salud en las unidades de salud. Los gestores respondieron el PCAToolBrasil, un cuestionario validado que mide el grado de asistencia primaria a la salud. Los odontólogos respondieron una versión del PCATool, adaptada y pre-testeada en servicios odontológicos. El análisis multinivel, basado en el modelo comportamental de Andersen, ajustó la variable de "haber consultado a un dentista alguna vez en la vida" a las co-variables contextuales e individuales. El estudio mostró una alta prevalencia de caries dental. Casi la mitad de la muestra tenía un historial de consulta odontológica alguna vez en la vida. $\mathrm{Ob}$ servamos gradientes sociales en el uso de servicios de salud bucal. A pesar de que no se haya conseguido eliminar el impacto de las condiciones sociales adversas, unos mayores niveles de atribuciones a la atención primaria en salud en servicios de salud bucal favorecieron el uso efectivo de esos servicios por parte de hijos de familias de baja renta.

Servicios de Salud Dental; Atención Primaria de Salud; Calidad, Acceso y Evaluación de la Atención de Salud; Preescolar
Submitted on $16 / \mathrm{Sep} / 2016$

Final version resubmitted on 23/Jan/2017

Approved on 06/Feb/2017 